\title{
A Comparative clinical study to evaluate the effect of Indigenous compound drugs (Shatavari mandoor and Pippali ghrita) in Parinama Shoola Vis-à-vis Acid Peptic Disorders
}

\section{Research Article}

\section{Pragya Singhal $^{1^{*}}$}

1. Clinical Registrar/ Asst. Professor (Kayachikitsa),

Ch. Brahm Prakash Ayurved Charak Sansthan, Khera Dabar, Najafgarh, New Delhi

\begin{abstract}
Background: : Acid peptic disease is the condition in which there is either excessive secretion of acid and pepsin or a weakened stomach mucosal defence, which is responsible for damage to the delicate mucosa and the lining of the stomach, oesophagus and duodenum resulting in ulceration.Parinama shoola in Ayurveda is comparable with Acid peptic disease.

Aim of study: The Aim of the study is to evaluate and compare the effect of indigenous compound drugs (Shatavari mandoor and Pippali ghrita) in uncomplicated cases of Parinam shoola.

Methods: This is a prospective, open labelled, randomised clinical trial. A total of 31 patients suggestive of features of Parinama Shoola (acid peptic disorder) were enrolled and were randomly divided in two groups- 12 patients were enrolled in group A and were given trial drug Shatavari mandoor, 19 patients were enrolled in group B and were given trial drug Pippali ghrita. Duration of study was 3 months.

Results: Individually both groups showed statistically significant improvement in clinical symptoms i.e. pain in abdomen, epigastric burning, nausea, flatulence, loss of appetite and constipation $(\mathrm{p}<0.01)$, but the mean reduction in the symptoms of group A (Shatavari mandoor group) is more than group B (Pippali ghrita group).

Conclusion: Both trial drugs are effective in the treatment of Parinama shoola. Shatavari mandoor is more effective in the treatment of Parinam shoola in comparison to Pippali ghrita.
\end{abstract}

Keywords: Acid peptic disorder, epigastric pain, Parinam a shoola, Peptic ulcer disease

\section{Introduction:}

An ulcer is defined as disruption of mucosal integrity of stomach and or duodenum leading to local defect or excavation due to active inflammation.

Peptic ulcers are estimated to occur in $6-15 \%$ of general population. The incidence of peptic ulcer declined steadily from 1960-1980 and then remained stable since then. (1)

The cardinal feature of peptic ulcer disease is epigastric pain which is characterised by gnawing or burning, may be ill defined, may be aggravated by meals or relieved few minutes after meals. Other associated symptoms include nausea, vomiting flatulence, abdominal distension, water brash etc.

In Ayurveda, Parinama shoola is a disease in which abdominal pain during digestion is observed. The

\section{*Corresponding Author:}

\section{Pragya Singhal}

Clinical Registrar/Assistant Professor (Kayachikitsa)

Ch. Brahm Prakash Ayurved Charak Sansthan,

Khera Dabar, Najafgarh

New Delhi

Mobile No.: +91-9999984610

E-mail: pragyasinghalagarwal@gmail.com aetiology, pathogenesis and clinical manifestation of Parinama shoola have got a striking similarity with acid peptic disorders in modern medicine.

The disease Parinama shoola was first mentioned by Madhavakara. In the aetio pathogenesis of Parinama shoola Madhavakar has given much importance to vata (2) in causing the disease, whereas Vijay rakshita in explaning the disease gave a specific and scientific pathogenesis of Parinama shoola. According to Vijay rakshita, Parinama shoola is a disease of tridosha, pitta predominance is present as the pain occurs during the period of digestion. (2)

In Parinama shoola abdominal pain occurs at the phase of digestion. 'Bhukte Jeeryati yata Shoolam Tadeva Parinamajam' (3)

Three dosas i.e. vata, pitta and kapha are involved in the pathogenesis of Parinama shoola. In all types of shoola (pain), vayu is the predominant causative dosha which is correlated with sympathetic nervous mechanism of sensation of pain in the abdominal visceral organ. Kapha refers to the kledaka kapha which has parlance with mucus gel layer and mucin of modern medicine. So kapha is for defensive mechanism in the pathogenesis of Parinama shoola.Pitta is related with HCL and pepsin and it is for aggressive mechanism causative for Parinama shoola. 
Two trial drugs, Shatavari mandoor and Pippali ghrita were selected for the present study.

Many previous studies (clinical and experimental) regarding the antiulcer effect of Shatavari mandoor were done, which showed promising results in cases of acid peptic disorders. $(4,5)$

Pippali ghrita has been described in Chakra dutta in the context of Parinama shoola. According to Chakra dutta, Pippali ghrita has been able to treat complicated cases of Parinama shoola. (6) and thus it was assumed that Pippali Ghrita would be beneficial in patients of Parinaana Shoola.

This study revealed the effect of herbomineral drugs (Shatavari mandoor \& Pippali ghrita) in the treatment of Parinama shoola.

\section{Material \& Methods}

Study design: It is a prospective, randomised, open labelled, parallel designed, clinical study.

\section{Inclusion criteria}

Patients showing clinical signs and symptoms suggestive of Parinama shoola like pain in epigastric pain, heartburn, acid eructation, water brash etc.

Subjects above 20 years and below 60 years

\section{Exclusion criteria}

- Pregnant and lactating mothers

- Patients having gall bladder disease, worm infestation, cardiovascular and liver disorders.

- Malignant and complicated ulcers

\section{Grouping of patients}

Patients were randomly divided into two groups

Group A: 12 Patients were included in group A and were administered with trial drug Shatavari mandoor.

Group B: 19 Patients were included in group B and were administered with trial drug Pippali ghrita.

\section{Criteria of assessment}

Clinical signs and symptoms: Udarasula (pain in abdomen), utklesa (feeling of nausea and vomiting), aruci (loss of appetite), hritkanțadaha (heart burn) etc. were assessed before and after the treatment. Clinical assessment was made by grading as $0,1,2,3$ on the basis of severity.

\author{
Grading pattern for signs and symptoms \\ Udar shoola (epigastric pain) \\ Grade-0: No Pain \\ Grade-1: Mild pain \\ Grade-2: Moderate pain \\ Grade-3: Severe pain
}

Hrikantha daha (burning in epigastric region)

Grade-0: No Heart burn

Grade-1: Occasional retrosternal burning

Grade-2: Retrosternal burning 1-2 times; relieved by food or antacids

Grade-3: Frequent retrosternal burning

Utklesh (nausea)

Grade-0: Absent nausea

Grade-1: Occasional desire to vomit

Grade-2: Frequent desire to vomit

Grade-3: Regular desire to vomit

\section{Adhmaan (flatulence)}

Grade-0: Absent feeling of gaseous distension

Grade-1: Occasional feeling of gaseous distension

Grade-2: Frequent feeling of gaseous Distension

Aruchi (loss of appetite)

Grade-0: Normal appetite

Grade-1: Mild loss of appetite

Grade-2: Moderate loss of appetite

Grade-3 Severe loss of appetite

Praseka (water brash)

Grade-0: No complaint of water brash

Grade-1: Occasional feeling of water

Grade-2: Frequent complaint of watery mouth

Grade-3: Regular complaint of watery mouth

\section{Treatment Protocol}

Trial Drugs

Table 1: Ingredients of trial drugs (all the parts of ingredients were taken by weight)

Shatavari Mandoor (7)

$\begin{array}{ll}\text { Shatavari swarasa } & 2 \text { parts } \\ \text { Mandur churna } & 2 \text { parts } \\ \text { Godugdha } & 2 \text { parts } \\ \text { Godadhi } & 1 \text { parts } \\ \text { Go Ghrita } & 1 \text { parts }\end{array}$

Pippali Ghrita (6)

$\begin{array}{ll}\text { Pippali Kawatha } & 4 \text { parts } \\ \text { Pippali Kalka } & 1 \text { part } \\ \text { Go Ghrita } & 1 \text { part }\end{array}$

\section{Method of preparation of trial drugs}

Method of preparation of Shatavari mandoor

Two parts of Mandoor bhasma, two parts of fresh juice of Shatavari swaras, two parts of cow's curd and milk and one part of cow's ghee were mixed and heated at low temp till the water content is evaporated and whole material becomes dry.

Dose: $1.5 \mathrm{gm}$. Bid

Mode of administration: Patients were advised to take the drug twice daily along with the meal. Drug is divided approximately into three parts, which should be taken in 
International Journal of Ayurvedic Medicine, 2015, 6(3), 267-271

the first, middle and last bolus of the food.

\section{Method of preparation of Pippali ghrita}

Four parts of Pippali kawatha, one part of Pippali kalka and one part of Go ghrita are mixed together and heated till ghrita is prepared

Dose: $5 \mathrm{gm}$. Bid

Anupana : Sukoshana dugdha (Luke warm milk)

\section{Follow up:}

Total duration of treatment was 3 months. The symptoms and signs of patients were recorded in detail once in a month before and during the treatment.

\section{Statistical analysis}

The data obtained in clinical studies before and after treatment was expressed in terms of mean, standard deviation. Appropriate t' test was applied to test the significance of comparative mean values of before and after treatment.

\section{Observation and results}

The study of demographic profile displayed that Parinama shoola was more prevalent among males $(60 \%)$, between the age group of $20-50$ years, most of the patients belong to rural areas $(63.3 \%)$, having spicy dietary habit $(37 \%)$ and vata-pitta deha prakriti (43.6\%), the sharad ritu (33.3\%) and rajasika manas prakriti $(66.6 \%), 20 \%$ of the patients were having anxiety and $13 \%$ of patients were having depression in the study. Regarding addiction $(6.67 \%)$ were addicted to smoking $(23.3 \%)$ to tobacco chewing and $(3.33 \%)$ to consumption to alcohol. [Table 2]

Most common symptoms observed were udar shoola (epigastric pain), hrikantha daha (burning in epigastric region), utklesh (nausea), adhmaan (flatulence) along with these, aruchi (loss of appetite), vibandha (constipation) and praseka (water brash) were also present in the patients of Parinama shoola.

In Group A significant improvement was observed in epigastric pain $(p<0.001)$, heart burn $(\mathrm{p}<0.01)$, loss of appetite $(\mathrm{p}<0.01)$, water brash $(p<0.02)$, flatulence $(p<0.02)$, constipation, $(p<0.02)$, nausea $(\mathrm{p}<0.01)$. [Table-3].

In Group $\mathrm{B}$ significant improvement was observed in epigastric pain $(\mathrm{p}<0.001)$, heart burn $(p<0.001)$, loss of appetite $(p<0.01)$, water brash $(p<0.05)$, flatulence $(p<0.01)$, constipation, $(p<0.001)$, nausea $(\mathrm{p}<0.01)$. [Table-3]

Table 2: Demographic profile

\begin{tabular}{|l|l|}
\hline Observations & Percentage \\
\hline Age \\
20 years-50 years & 86.6 \\
\hline Sex & \\
Male & 60 \\
Female & 40 \\
\hline
\end{tabular}

\begin{tabular}{|l|l|}
\hline Observations & Percentage \\
\hline Habitat & \\
Rural & 63.33 \\
Urban & 36.66 \\
\hline Addiction & \\
Tobacco & 23.33 \\
Smoking & 6.67 \\
Alcohol & 3.33 \\
\hline Deha prakruti & \\
Vataja & 18.33 \\
Pittaja & 21.66 \\
Väta-paittika & 43.66 \\
\hline Manasa Prikriti & \\
Rajas & 66.6 \\
Tamas & 33.3 \\
\hline Psyche phenomenon & \\
Anxiety & 20 \\
Depression & 13.33 \\
\hline Dietary habits & \\
Spicy food & 37 \\
\hline Kala & \\
Sarad ritu & 33.3 \\
Hemanta ritu & 23.3 \\
Vasanta ritu & 16.6 \\
\hline
\end{tabular}

Table 3: Effect of treatment on clinical sign and symptoms

\begin{tabular}{|c|c|c|c|c|c|}
\hline $\begin{array}{l}\text { Clinical } \\
\text { signs \& } \\
\text { symptoms }\end{array}$ & $\begin{array}{l}\text { Gro } \\
\text { up }\end{array}$ & $\begin{array}{l}\text { BT } \\
\text { Mean } \\
\pm \text { SD }\end{array}$ & $\begin{array}{l}\text { AT } \\
\text { Mean } \\
\pm \text { SD }\end{array}$ & $T$ & $\mathbf{P}$ \\
\hline \multirow[t]{2}{*}{$\begin{array}{l}\text { Udarasu- } \\
\text { la }\end{array}$} & A & $\begin{array}{l}2.58 \\
\pm 0.51\end{array}$ & $\begin{array}{l}0.75 \\
\pm 0.45\end{array}$ & 11.0 & $\mathrm{P}<0.001$ \\
\hline & B & $\begin{array}{l}2.58 \\
\pm 0.51 \\
\end{array}$ & $\begin{array}{l}1.74 \\
\pm 0.45 \\
\end{array}$ & 9.8 & $\mathrm{p}<0.001$ \\
\hline \multirow[t]{2}{*}{ Aruchi } & $\mathrm{A}$ & $\begin{array}{l}1.33 \\
\pm 0.98\end{array}$ & $\begin{array}{l}0.42 \\
\pm 0.51\end{array}$ & 4.0 & $\mathrm{p}<0.01$ \\
\hline & B & $\begin{array}{l}1.05 \\
\pm 1.18\end{array}$ & $\begin{array}{l}0.58 \\
\pm 0.69\end{array}$ & 3.37 & $\mathrm{p}<0.01$ \\
\hline \multirow[t]{2}{*}{ Utklesa } & $\bar{A}$ & $\begin{array}{l}1.08 \\
\pm 1.00 \\
\end{array}$ & $\begin{array}{l}0.42 \\
\pm 0.67 \\
\end{array}$ & 4.69 & $\mathrm{p}<0.01$ \\
\hline & B & $\begin{array}{l}1.37 \\
\pm 0.90\end{array}$ & $\begin{array}{l}0.95 \\
\pm 0.71\end{array}$ & 3.62 & $\mathrm{p}<0.01$ \\
\hline \multirow[t]{2}{*}{$\begin{array}{l}\text { Hritkan- } \\
\text { thadaha }\end{array}$} & $\mathrm{A}$ & $\begin{array}{l}1.83 \\
\pm 0.94\end{array}$ & $\begin{array}{l}0.92 \\
\pm 0.67\end{array}$ & 4.75 & $\mathrm{p}<0.001$ \\
\hline & B & $\begin{array}{l}1.89 \\
\pm 0.81\end{array}$ & $\begin{array}{l}1.26 \\
\pm 0.69\end{array}$ & 5.53 & $\mathrm{p}<0.001$ \\
\hline \multirow[t]{2}{*}{ Adhmana } & A & $\begin{array}{l}0.75 \\
\pm 0.62 \\
\end{array}$ & $\begin{array}{l}0.33 \\
\pm 0.49 \\
\end{array}$ & 2.80 & $\mathrm{p}<0.02$ \\
\hline & $\mathrm{B}$ & $\begin{array}{l}1.21 \\
\pm 0.79 \\
\end{array}$ & $\begin{array}{l}0.74 \\
\pm 0.56 \\
\end{array}$ & 2.96 & $\mathrm{p}<0.001$ \\
\hline \multirow[t]{2}{*}{ Praseka } & $\mathrm{A}$ & $\begin{array}{l}0.83 \\
\pm 0.83\end{array}$ & $\begin{array}{l}0.42 \\
\pm 0.51\end{array}$ & 2.80 & $\mathrm{P}<0.02$ \\
\hline & $\bar{B}$ & $\begin{array}{l}0.42 \\
\pm 0.77 \\
\end{array}$ & $\begin{array}{l}0.21 \\
\pm 0.45 \\
\end{array}$ & 2.14 & $\mathrm{p}<0.05$ \\
\hline \multirow[t]{2}{*}{ Vibandha } & $\bar{A}$ & $\begin{array}{l}1.17 \\
\pm 1.03 \\
\end{array}$ & $\begin{array}{l}0.58 \\
\pm 0.67 \\
\end{array}$ & 3.02 & $\mathrm{p}<0.02$ \\
\hline & B & $\begin{array}{l}1.21 \\
\pm 0.71\end{array}$ & $\begin{array}{l}0.58 \\
\pm 0.51\end{array}$ & 5.55 & $\mathrm{p}<0.001$ \\
\hline
\end{tabular}


Discussion:

Acid peptic disorder becomes a significant problem in the medical world because of its higher incidence, incomplete aetio-pathogenesis, relapse and severe consequences. In spite of phenomenal process in H. pylori researches a great relapses in APD are found. A relative failure of modern medicine has made the majority of population to turn towards alternative system of medicine.

In the present study regarding age, high incidence was observed in between $2^{\text {nd }}, 3^{\text {rd }}$ and $4^{\text {th }}$ decade of age group which may be due to pitta predominance in this age. In this study males were $60 \%$ and $40 \%$ were females. Thus it appears the disease of male predominance.

Vata-pitta trait of deha prakriti (43.33\%) and rajasika type of manasa prikriti $(63.33 \%)$ persons are more prone to acid-peptic -diseases. Thus suggesting that Parinama shoola is a vata-pitta predominant disease.

Certainly, the influence of kala (season) is present in Parinamashoola.It has been indicated in this study in the form of high incidence $(33.33 \%)$ of the disease in patients during Sharad ritu (autumn season). Sharad ritu has been considered as the pitta prakopaka kala, thus the incidence of the disease in this kala suggests the prominence of pitta in Parinama shool.

Observations regarding dietary habits showed that people who used to take spicy diet were more prone to develop this disease than those patients who were taking ordinary diet, thus suggesting that pitta prakopaka ahara (aggravating diet) aggravates the disease, indicating that Parinama shoola is a pitta predominant disease.

Statistical data revealed that the trial drugs showed statistically significant improvement in udar sholoa, aruchi, utklesha, hritkantha daha, adhmana, vibandha, and praseka $(\mathrm{p}<0.01)$

In udarshoola (epigastric pain), both the trial drugs showed statistically highly significant improvement $(p<0.001)$, but the mean decrease in the intensity of epigastric pain of group B was found lesser as compared to group A, which suggested that trial drug Shatavari mandoor is more effective in improving epigastric pain in comparison to Pippali ghrita in patients of Parinama shoola.

Similarly, both the trial drugs also showed statistically significant improvement $(\mathrm{p}<0.001)$ in hrit kantha daha (epigastric burning), but the mean decrease in this symptom in group A was more in comparison to group B, thus indicating that Shatavari mandoor is having more pitta shamak action in comparison to Pippali ghrita.

Statistical data revealed that, constipation is significantly reduced in both groups at the end of the treatment but highly significant improvement was observed in group B $(\mathrm{p}<0.001)$. Also, group B showed highly significant improvement in flatulence $(p<0.001)$ in comparison to group A $(\mathrm{p}<0.01)$, thus indicating the vata shamak action of Pippali ghrita.

\section{Mode of action of trial drugs:}

Trial drug Shatavari mandoor is a herbomineral compound which consists of Mandoor bhasma, Shatavari swaras, Goghrit, Godugha, and Gavya dahi. (7)

Pharmacological properties of Shatavari (Asparagus racemosus) are madhur tikta rasa, pichalasnigdha guna, sheeta veerya and madhur vipaka (8).

Several clinical studies showed the antiulcer effect of Shatavari. $(9,10)$

Mandoor is kashaya in rasa, sheeta, guru, pitta shamak in guna (property). Go dudha and Go ghrita are sheeta, madhur and vata-pitta nashaka.

These properties of Shatavari Mandoor helps in pacification of pitta and vata,(7) which are the main aggravating factors in the pathogenesis of Parinama shoola.

Also several clinical studies regarding the antiulcer properties of Shatavari mandoor have been conducted and revealed its antiulcer effect owing to strengthen mucosal defence mechanism in acid peptic disorders. $(4,5)$

Second trial drug is Pippali ghrita which consists of Pippali kawatha, Pippali kalka, Go ghrita.(6)

Pippai (Piper longum) is katu rasa pradhan, snigdha and ushna in guna (property) and vatanulomak in action. (11)

Pippali can act as vatanulomak (pacifies abdominal gases) and shoola prashmak due to its snigdha -ushna guna, agni deepan (improving digestive fire) due to katu rasa. Ghrita is having the property of vata- pittahara, shoola-prasamana (pain relieving), snehana, agnideepan (improving digestive fire). Ghrita has also been claimed a good vranaropak.(ulcer protective property). Thus drug may act as cytoprotective (barrier of acid-pepsin in the epithelial lining of stomach, duodenum) in the patients of Parinama shoola.

An experimental study, has also showed antiulcer effect of Piper longum in rats. (12)

Thus, the antiulcer property of the trial drugs Shatavari Mandoor and Pippali ghrita, is probably owing to their cytoprotective, shoola prashmak and vatanulomaka action.

\section{Conclusion:}

This is evident from both clinical and statistical improvement that the drugs Shatavari mandoor and Pippali ghrita are effective in the treatment of Parinama shoola and their ulcer protective effect may be through promotion of defensive mucosal mechanism rather than affecting the offensive acid-pepsin secretion.

It was observed that, Shatavari mandoor is more effective in relieving symptoms like burning sensation whereas Pippali ghrita is more effective in relieving symptoms like flatulence and constipation in patients of 


\section{Parinaam shoola.}

Thus, it can be concluded from the present study that Pippali ghrita would be effective in vata predominant Parinaam shoola and Shatavari mandoor would be effective in pitta predominant Parinaam shoola.

\section{References:}

1. Harrison's Principle of Internal medicine. $16^{\text {th }}$ Edition Vol. 2.Peptic ulcer disease and related disorders.

2. Madhavkar, Madhav Nidan with Madhukosha Sanskrit commentary by Vijay Rakshita, Srikanta Dutta, Hindi commentary by Brahm Shankar Shastri. Chapter 26 Verse 15. Varanasi. Chaukhambha Sanskrit Sansthan; Reprint 2012. Page 183.

3. Madhavkar, Madhav Nidan with Madhukosha Sanskrit commentary by Vijay Rakshita, Srikanta Dutta, Hindi commentary by Brahm Shankar Shastri. Chapter 26 Verse 16.Varanasi. Chaukhambha Sanskrit Sansthan; Reprint 2012. Page 183.

4. Sailaja and Tiwari SK. A Clinical study / biochemical study in treatment of Parinama shoola vis-à-vis acid peptic disorder with Shatavari Mandoor. MD Thesis, BHU.Varanasi. 2000.

5. Prasanna Lakshmi NC, Tiwari SK. A Clinical study in treatment of Parinama shoola vis-à-vis acid peptic disorder with Shatavari Mandoor. MD Thesis, BHU. Varanasi. 1999.
6. Chakrapani, Chakradatta. Commentry by Ravidutt Shastri. Parinama Shoola Rogadhikar. Chapter 27.Verse-25. Varanasi.Chaukhambha Subharti Prakashan. Reprint 2006. Page 127.

7. Chakrapani's Chakradatta.Commentry by Ravidutt Shastri. Parinama Shoola Rogadhikar. Chapter 27.Verse-34,35, 36. Varanasi.Chaukhambha Subharti Prakashan. Reprint 2006. Page 128.

8. Bhavmishra's Bhavprakash Nighantu.Commentry by KC Chunekar. Edited by GS Pandey. Guduchiyadi verga.verse 186-187. Varanasi.Chaukhambha Bharti Academy. Reprint 2010. Page No 378.

9. Maheshwari C M, Chaturvedi GN. Clinical correlation of Parinama shoola and its treatment with indigenous drug Shatavari.MD Thesis, BHU. Varanasi.(1977)

10. Singh KP, Singh RH. Clinical trial on Shatavari in Peptic ulcer. Journal of Research in Ayurveda and Siddha. 1986. Vol. 3(3-4). P 91-100.

11. Bhavmishra's Bhavprakash nighantu.Commentry by KC Chunekar, edited by GS Pandey. Haritkayadi verga.verse 54.Varanasi. Chaukhambha Bharti Academy. Reprint 2010. Page 15.

12. Agarwal AK, Sairam M, Rao V, Goel RK.Effect of Piper longum Linn,Zingiber officinalis Linn, and Ferula species on gastric ulceration and secretion in rats. Indian Journal of Experimental Biology. Oct 2000.Vol. 38. P994-998. 